\title{
THE POLISH MOTHER ON THE DEFENSIVE? THE TRANSFORMATION OF THE MYTH AND ITS IMPACT ON THE MOTHERHOOD OF POLISH WOMEN
}

\author{
AGNIESZKA IMBIEROWICZ \\ agnieszka.imbierowicz@gmail.com \\ University of Wrocław, Poland
}

\begin{abstract}
The subject of this presentation is the attempt to define and to present the origins, socio-cultural content and the evolution of The Polish Mother myth, present in the polish national consciousness. The author tries to show how this myth was born, what functions it fulfilled and what forms it took in the changing historical and social reality, from the moment of loss of independence, through a period of real socialism, until the present day. The impact of this myth in the lives of real women and their motherhood is taken into consideration. Then, the author comparing the results of the latest polish sociological researches on the family and its transformation, and transformation of value systems together with theories about the specifics of life in the period of postmodernity, wonders whether it's time to deconstruct the myth of The Polish Mother, because it does not fit the conditions of today's world, which is characterized, above all, by the apotheosis of individuality, self-realization and freedom, or perhaps in polish society there is still strong traditionalism in thinking about motherhood, and the myth of The Polish Mother is still alive?
\end{abstract}

Key words: Polish Mother, national myth, motherhood, woman, transformation of value systems, postmodernity.

\section{WHO WAS AND WHO IS THE POLISH MOTHER?}

The Polish Mother has featured in the collective consciousness for many years, functioning as a social myth ${ }^{93}$. Why do we actually see it in these categories? Well, "myths belong to the vast class of beliefs (...). These are the judgments which the individual shares with his social group, usually under its influence; and are closely related to the functioning and the fate of a given group (...). Participation in social beliefs is governed by the laws of cultural transmission, in which on the one hand works the mechanism of imitation, on the other hand the impact of anonymous authority, which is a social group for its member, who identifies with it"94 (Marciszewski 2011). Importantly, the myths are determined by the value system of the given community, for example, The Polish Mother is the result of polish traditionalism, conservatism and catholic values. Martin Punpur, claims that every

93 This subject is discussed by historians, sociologists, philosophers and representatives of gender studies. See: Kowalczyk 2011; Walczewska 1999; Titkow, Duch-Krzystoszek, Budrowska 2004.

94 All translations in this article are made by the author. 
myth can be described by referring to three functions, namely: hermeneutic, integrating, and therapeutic, and it seems that at least two of them can be related to the myth of The Polish Mother (Punpur 2011). In fact, this myth describes the world, gives it meaning, "constitutes the identity of the individual and shapes its attitude towards reality" (Punpur 2011). It also integrates community, strengthens the links between its members through the validation of certain norms, values behavior patterns. On these last it has influence at least through a system of do's and don'ts. Moreover, you can find an analogy in the sense ascribed once to stories about Greek heroes and tales about The Polish Mother, because in both cases the goal is "to provide the ideals of noble and dignified life. In concreto, it manifests itself in being a model and example for others to follow" (Punpur 2011).

In fact, The Polish Mother is a pattern of femininity, the effect of our complicated history that created the image of a heroic woman, capable of incredible sacrifices for the good of the homeland, focusing primarily on family, not on herself. Historical turbulences of our statehood dictated, that it is them, women, that were obligated to raise their children in a spirit of profound patriotism, take care of continuity of the language and culture, but also send their sons to certain death in the name of the common good. At the same time they had to take care of the entire households, while their husbands were absent fighting for Poland. The vastness of issues which they needed to tackle, combined with emotional challenges, inspires admiration and still affects the mentality of many Polish women.

Anna Titkow, Danuta Duch-Krzystoszek and Bogusława Budrowska, while examining problems of modern Polish women, use the locution "Polish Mother" to describe a certain type of woman: "overloaded, devoting themselves to their loved ones, convinced of their irreplaceable skills, [acting as the - footnote author] managers of family life" (Titkow, Duch-Krzystoszek, Budrowska 2004, p. 65). Research, which was carried out by them in 2002 on a representative sample of the Polish population shows that the image of The Polish Mother consists of the following self-commentary of women: "without my sacrifice my family would not manage", "I bear on my shoulders so many things, that they would be enough for several other women", "I prefer to do most things on my own, because no one will do them so well as I do", " often at home I will do something alone rather than ask someone for help" (Titkow, Duch-Krzystoszek, Budrowska 2004, p. 65- 66). Thus, features that constitute this type of woman is above all hard work, devotion, ability to sacrifice, the belief of being irreplaceable in carrying out housework, a kind of multifunctionality in realizing these tasks and taking care of the family.

By practicing such an attitude, a woman can somehow limit her subjectivity, since her behavior is determined not by her internal, very personal desires, but by the social expectations addressed to her and tasks arising from her motherhood. She is defined by a cultural script of being a mother, a perfect mother. Subjectivity, understood as "the one's ability to influence the events in the external world around him and in him, while still maintaining fullest possible autonomy" (Sulik 2010, p. 14), is questionable, especially when it comes to women, who more or less consciously inscribe in the myth of The Polish Mother. Repeatedly they reduce their femininity, and perhaps even whole being to the motherhood, which, accor- 
ding to B. Budrowska can be defined as "total institution" (Budrowska 1997, p. 297) referring to the similarities between the situation of mother, and people who are in total institutions within the meaning conceived by Erving Goffman. The author of this definition believes that becoming a mother is a turning point in woman's life because it introduces significant changes in her biography, modifies goals and priorities but also leads to "redefine the experience of time" (Budrowska 1997, p. 301), introduces "processual time" to the existence of woman. Karen Davies (Davies 1994) wrote about it, stating that child care takes the woman's every moment, and this time "refers (...) more to the tasks and the perceived needs of the people under her care than the clock that determines time relationships. Things take as much time as they need, and are quietly immersed in other activities" (Budrowska 1997, p. 303). The child and its needs become the center of mother's activity, which is normal, but can also be an alarming phenomenon when a woman at all costs tries to incorporate the role of the perfect mother.

\section{THE RECIPE FOR A POLISH MOTHER, THE WELL-KNOWN THREAD OF POLISH MARTYROLOGY}

This pattern of woman did not arise out of nowhere. Mostly, its origins are believed to be the result of the difficult history of the Polish nation, especially in times of the Polish partitions. "Women stood then in front of the various kinds of tasks. The guarantee of maintenance of the national identity was the appropriate upbringing of children, so it became a political matter (...). When men were in prison, in exile or were involved in the armed uprisings, from which they often did not return, women were engaged in running the farm or business. And they lived up to all of these roles extremely well. The need to meet these various obligations led to formation of the syndrome of the heroic Polish Mother, capable of bearing every burden" (Budrowska 2000, p. 93). Man fought for the Motherland, was involved in politics, and "women's role was simply to endure everything and admire" (Środa 1992, p. 10), as well as to give birth to successive generations of Poles - patriots. Her responsibility was to ensure continuity of Polish culture, language, customs - so it can be said that she realized unconsciously the feminist postulate that much later appeared in Western feminism, namely "the personal is political"

The role of such education can be seen in the line of Adam Mickiewicz To The Polish Mother, in which he concluded the conviction that the duty of the title mother is preparing her son for the role of conspirator and future martyr for the national cause. The fate of this mother is tragic, since she realises that her child may not be glorified because of the conspiratorial nature of his struggle, or even having a real awareness of the risk of losing a beloved son, she must raise him so that in future he will be ready to give his life for his country. Here is visible the analogy to the fate of Virgin Mary, who also had to reconcile with the death of her

95 The slogan "the personal is political”, in the context of the educational work of Polish women at the time of loss of the statehood, can be interpreted as a form of being responsible by them for the nation and its fate. By contrast, according to some feminists, such as Catherine McKinnon, making political what is private, such as domestic violence, can be emancipatory strategy and publicizing such problems may show the need for systemic solutions. 
son in the name of a higher purpose. Also, looking through the prism of Polish messianism, we can conclude that if the great mission of the Poles was widely understood as the salvation of nations, the crucial task assigned to the women, was the education of the future generations in the spirit of that mission. The Polish Mother can thus be read as "formula of women's participation in Polish national community. For a woman in Poland motherhood is to ingratiate oneself in this community" (Walczewska 1999, p. 53).

After a period of loss of statehood, it was in the time of two World Wars, when women once again faced with the dilemma, that can be described as a classic example of tragic conflict: on the one hand a duty to the Motherland, and thus - the need of spreading patriotism - upbringing based on the ideals of national heroes prepared to sacrifice their lives for the glory of the motherland, and on the other hand, the obligation towards the family, the mother's love towards children, care for their development and simultaneously life in the sense of fear arising from the possibility of their loss.

\section{THE SOCIALIST POLISH MOTHER}

The times of real socialism were no less demanding for Polish women: when on the one hand, they played a food-acquiring role while standing in the mile-long food queues, "the gastronomic mothers" (Walczewska 1999, p. 165), who ruled the house using a specific weapon, which was then the monopoly of the kitchen power, at the same time also working professionally. Their situation is described by Sławomira Walczewska who uses the term "home matriarchy" (Walczewska 1999, p. 164-169) and defining it as a situation in which woman has power over the rest of the family, but within a very narrow range, which includes the area of the household only. In addition, this authority is ransomed by many sacrifices, a lot of time, labor and fatigue. It can therefore be concluded that the significance of the power wielded by women in general is limited, and it seems to lose more of its importance when juxtaposed with that represented by men, because in fact is not the woman who makes the decisions on important matters that take place in the public sphere, and has huge impact on the private sphere, for example the shape of the economy at that given time.

On the other hand, Polish women at the time of People's Republic of Poland were often incorporated into the role of the opposition Polish Mother, "a mainstay of the house, where patriotic values are nurtured, home, where you listen to Radio Free Europe, and the duplicator prints opposition newspapers and flyers (...). During the dramatic moments of worker's strikes, The Polish Mother again must make sacrifices, suffer, once again she becomes the tragic mother. In one of the opposition songs about Janek Wiśniewski, there are words: „Do not cry mothers, it was not for nothing... "" (Kowalczyk 2011). Also meaningful was the inscription on the walls of the striking Gdańsk shipyard: "Women, do not disturb us, we are fighting for Poland". These women from the NSZZ "Solidarność" (Independent Self-governing Labour Union "Solidarity"), assuming the role of the invisible, by limiting their activities only to supporting their brave men, suffering and waiting, con- 
demned themselves to a lack of recognition and appreciation of their sure effort for the sake of the success of the common cause (Rutkowska 2011). S. Walczewska interprets this as one of the many proofs of the existence of "nobility - knightly gender contract" (Walczewska 1999, p. 11), which is "a decisive factor for the specificity of women's emancipation discourse in Poland (...). A woman encouraging a man to fight for the motherland, pinning a bow to his breast, woman as a Samaritan, devoting herself, healing his wounds - is its catholic-national variation [nobility - knightly gender contract - footnote author]. In the liberal discourse a knight is a gentleman adoring his lady, in the discourse of socialism he is a gallant social activist dealing cloves »to our beautiful ladies « at the Academy of Women's Day" (Walczewska 1999, p. 11). The functioning of "nobility - knightly gender contract" is very dangerous for the existence of emancipatory discourse in Poland, because it creates the illusion that women in Poland have always been surrounded by extraordinary honor, reverence, adoration almost, and creates the conclusion that movements fighting for gender equality are unnecessary in this country, for emancipation has already taken place.

\section{"ORDINARY WOMAN" VS. FEMINISTS, THAT IS, WHO NEEDS FEMINISM IN POLAND}

At last The Polish Mother often takes the form of "ordinary women", also very often she is characterized as being in opposition to feminists, which may suggest that the feminist movement is not needed. At the same time it is worth nothing that the conviction of the obsolescence of this movement in Poland is most common in the right wing discourse. Exemplification of this can be an article by Rafał Ziemkiewicz "Male, female, Polish", in which he puts the thesis that Poland is a matriarchal country - after all, "Polish women are in a much better position than female residents of the countries from which they are importing feminism to us" (Ziemkiewicz 2011), because, as he writes, in comparison with other countries, in Poland we have the largest number of women engaged in small and medium sized businesses. Unfortunately, he doesn't write why this situation is taking place, and according to a World Bank report, a fairly frequent reason for them opening their own business is unemployment and lack of career prospects (Paci 2004, p. 55-56; Lisowska 2011). Then, we read in the R. Ziemkiewicz's article, how positive the statistics are on the participation of women in management, scientific and managerial staff. Also in this case knowledge that the reader is given, is selective and incomplete, because, although the percentage of women in leading positions in Poland is relatively high, it should be noted that it concerns only the management of low and middle managers, not the highest, and therefore it is an example of the existence of the phenomenon called "glass ceiling", both in business and politics (Titkow 2003; Puigamau 2009, p. 18; Dmochowska 2007, p. 227- 243). Moreover, according to R. Ziemkiewicz, a woman is portrayed in Polish culture "as a person who transfers the heritage of generations, saving them and resurgenting" (Ziemkiewicz 2011), and further evidence of the privileged position of women in Poland, the author sees in the religious layer: "Catholicism in which, after all, the maternal 
element submitted more than the paternal element" (Ziemkiewicz 2011). Along with glorifying the status of women in Polish society, R. Ziemkiewicz presents an attitude deeply discrediting to feminism, claiming that it is unnecessary in Poland, as "it reduces women's issues to slogans as questionable as facade parities" (Ziemkiewicz 2011) but not really caring, according to a publicist, about the interests of the mothers. R. Ziemkiewicz's statement may suggest that he does not see the importance of parity, and that it is for example the stimulation of democracy and giving a chance to half of Polish citizens to find their representation in the structures of power, according to the title of the first Manifa (feminist manifestation): "Democracy without women is half democracy". Likewise, by taking criticism of accused feminism, this time - as a movement insensitive to the needs of Polish mothers - R. Ziemkiewicz simplifies and abuses it, because in Poland there are feminist foundations and associations like MaMa Foundation or Konsola Association of Women, in whose statutes support for mothers is entered as a primary objective.

Unfortunately, titles of articles like this one which appeared in the "Polityka" in 2003, are no longer surprising: Women against feminists (Kobiety przeciwko feministkom 2003, p. 13) - which describes the protest of "ordinary women", in this case predominantly catholic, against the government's program to liberalize the law concerning the anti-abortion act and funding contraceptives from the budget, which they considered to be full of "extreme feminist solutions" (Kobiety przeciwko feministkom 2003, p. 13) - or Feminism is striking the woman from a catholic portal fronda.pl (Brzezińska 2011). Compilation of the opposition of "ordinary women" versus feminists is to suggest that feminism is not needed in Poland and that it is contrary to the traditional values Polish women which can be regarded as a family orientated, and Catholic.

In an emphatic, and no less absurd way, the problem is illustratated by the blog Hammer on atheists (http://mlot.blogspot.com/search/label/Feminizm) founded by two student-catholics, cited in the aforesaid article, Feminism is striking the woman (incidentally written by a woman): "Is it really for the good of women [feminism - footnote author]?. Why does not any feminist protest against women's image promoted in the media, as an object used for sexual needs? Why, instead of aparity act or other legal crap will they not put through Parliament laws prohibiting pornography or brazen acquisition of contraceptives by gynecologists, as a cure for every problem? Why will they not start an information campaign on how very harmful, especially carcinogenic, are artificial means of contraception? Why have feminists not warned future mothers how expensive, ineffective and especially humiliating for a woman it is to use the method of in vitro? What a moral blow to the mother is abortion?" (http://mlot.blogspot.com/search/label/Feminizm). Superficiality and one-sidedness of such reasoning is probably obvious, and the text itself is full of ideology, innuendo and conspiracy theories, but it also well illustrates the fact that feminism in the discourse of the right wing is seen as opposed to Catholicism, family and tradition, and even harmful to the health of women- simply as a movement that can only harm the Polish women.

In this context it is worth explaining how this sudden revival of right-wing discourse in Poland in recent years happened. I will cite two arguments: the Polish 
system transformation expert, David Ost and the Polish feminist, Agnieszka Graff. D. Ost sees the reason for this political return to the right side in the activities of "Solidarność", which after 1989 could not orchestrate naturally occurring social anger around categories of different social group interests, but the issue of identity was made paramount. "It paved the way for the anti-liberal culture, which has burgeoned over the process of democratization in Poland since then" (Ost 2007, p. 365) and excludes many groups of citizens, making them "strangers". The right wing acquired electorate in large part due to the fact that other political forces have disappointed it. The heritage of "Solidarność" ("Solidarity") concerning identity divisions inherited such political parties as Samoobrona (Self-Defense), Liga Polskich Rodzin (The League of Polish Families) and Prawo i Sprawiedliwość (Law and Justice), which to this day successfully continue the rhetoric of exclusion, thus undermining the existence of a genuine democracy and civil society in Poland, treating, among others feminists as an enemy of the Polish people and putting them in opposition to the hallowed tradition of The Polish Mother.

A. Graff (Graff 2008) claims in turn that the polish accession to the European Union has revived some nationalists concerns and defensive reactions of conservative groups, who regard the EU countries as supposedly too liberal in lifestyle. Therefore, the representatives of the Polish right wing, ensuring continuity of Polish national identity, so strongly emphasize the distinctiveness of Poland, its uniqueness in Europe, paying attention to its high level of moral traditionalism, conservatism, respect for the traditional, heterosexual family, etc. (Graff 2008, p. 15-16). Of course, the ideal of The Polish Mother, cultivating all these values and opposition to abortion, in vitro, contraception and civil partnership again becomes prominent in this context. The emphasis here is primarily on abortion because "having children is treated as a fulfilling the national requirement. This is primarily about visions of our nation's demographic decline spreading through pronatalists. As a result, present-day Polish Mothers are opposed to the feminists, which should not be surprising, considering how much The Polish Mother has always been a patriarchal structure" (Kowalczyk 2011).

\section{CLIMACTERIUM VS. MOTHERLAND - ABOUT INVALIDITY OF POLISH WOMEN IN FLESH AND BLOOD}

The Myth of The Polish Mother was and still is a real challenge for Polish women, because the crossbeam of moral immaculateness was placed very high. In the end caring for the welfare of the Motherland, the attitude presenting devotion with virtually no limits, a comparison to the Mother of God- all this entails. The Polish Mother is an ideal woman, devoid of selfishness, and even her own body. Her mission is to provide for Motherland citizens raised in a spirit of patriotism total dedication to motherhood, and in implementing these obligations there is no place for such trivial things, like physicality. "We need to point out that The Polish Mother was actually deprived of a body. It is only an apparent paradox, because if you treat her as a structure, it is worth noting that physical issues were 
eliminated from her (...). The Polish Mother is so much a paper form that you can have the impression that problems such as menstruation, the pain of childbirth, menopause do not apply to her. After all, she entirely renounced herself, and her physiological issues compared to the Motherland's matters appear to be frivolous and unworthy of consideration. In every conversation she always appeared only as a mother, but it is not known how it happened that she became a mother. Physiology and physicality remain fully rejected as unsuitable for the myth, the more The Polish Mother was seen in terms of the secular equivalent of the Virgin Mary" (Kowalczyk 2011).

About the latter, there is a very interesting article by Magda Łazar-Massier called Mary corporal, in which we can read that "the secret of giving life, giving birth - which is the basis of so many religions, in Christianity is focused on the figure of Mary. This character embodies the Christian ideal of womanhood, which includes the relationship to sexuality, body, sensuality and femininity itself" (Eazar-Massier 2011). The Virgin Mary is an example that Christianity makes the strong linkage between physicality and sinfulness, as well as between purity and holiness. The Catholic Church emphasizes her virginity, and when speaking about sex, its procreative function is at the forefront. The Statue of Mary was stripped of sensuality, a characteristic of her predecessors, goddesses of fertility. About the catholic Great Mother we say: immaculate, pure, virginal, and her physicality usually remains hidden. It can be said that Mary was reduced to the role of mother, her sexuality does not exist, and she is above all quiet, humble, always obedient to God. This picture of the Virgin Mary is so important that as Magdalena Środa marks, Catholicism in Poland cannot be seen solely in terms of religion. It should be remembered that it also has essential educational and socialization functions and describes how the various roles in society should be fulfilled - including the role of the mother (Środa 1992, p. 13). So if the Virgin Mary was characterized by some specific virtues, polish mothers should strive for them.

The Polish Mother is a figure devoid of body and eroticism, which in fact are irrelevant in the face of its supreme role - motherhood. And even though it is a phenomenon most immersed in the sphere of physicality, in her case it is reduced to the role which is mainly symbolic, spiritual, even metaphysical. Also today, the issue of women's physicality is both a symbolic and political matter. Politicians together with various associations, social movements are fighting for a right to decide about it. The ideal exemplification of this is a dispute about abortion. The pro-choice side argues that the legal sanction of choice is crucial because it involves issues such as personal freedom, autonomy, respect for women and their right to decide for themselves, shaping their lives at their own will. The opponents of abortion, people identifying with the pro-life movement, emphasize the moral importance of motherhood, evaluate life of the unborn child (by their opponents-fetus) more than the life of the mother, whose real-life problems are completely ignored. In this way, women are deprived of their physicality, and with it - subjectivity. It is depriving them of the right to decide for themselves, because in this case, "the personal is political" and the single woman's motherhood is not only her matter but a matter of national importance. At the same time politicians (mostly 
men) feel allowed to impose their will on all the Polish women, regardless of their financial situation, health status, religious beliefs, personal value system, and finally common desire to be a mother or absence of it. Such a woman, remaining passive to interference in the scenario of her own life, humbly accepting another's burdens and limitations, is the newest incarnation of The Polish Mother. Even in the parliamentary debate on maternity leave, Law and Justice MPs more often referred to the child's welfare than the life-giving women, creating the impression that this leave is not really designed for the mother (Graff 2008, p. 145-147).

In conclusion, on reflections on the myth of The Polish Mother we can settle on the basis of two aspects: the idealizing and the tragic, while the second results from the first. Based on the idealizing aspect - we see a woman reduced to the role of a heroic, self-sacrificing, virtuous mother, similarly, that of the ladies who cannot find themselves in such a role or try to fight with the normative influence of the society, awaiting a kind of ostracism. Reducing womanhood to motherhood in Poland led to unhappiness of many women who feel the stigma of childlessness, or are mothers against their will, and fate of them all shrouded in taboo.

\section{IS IT TIME TO OVERTHROW THE MYTH?}

Incentive to write this article was a reflection, whose object was the question of the validity of the myth of The Polish Mother, about whether it affects motherhood of Polish women, and how its potential impact is manifested and whether there is a possibility, perhaps even the necessity for its overthrow. In order to answer these questions I will briefly outline the major trends in the context of changes in the sphere of family and procreation. Of course, the transformations that occur in them are not directly conditioned by the myth of The Polish Mother, hence we cannot speak about its monopoly on the attitudes and behavior of Polish women. But we must be, however, aware, that as a national myth it contains a lot of our history, traditions, mentality, so it is legitimate to presume that it may at least partially affect the motherhood of Polish women, for example through social pressure that it produces. On the other hand, it seems that transformations of the modern social world, including the family, influence this myth and show that its power is weakening.

We live in a world that is called postmodern (Bauman 2004; Beck 2002) by some and whose characteristics are e.g. consumerism, individualism, denying the great narratives subjectivization, secularization, laicization, the perception of freedom as supreme value, cultural pluralism, crisis of traditional authority and transformations in relationships. All this to some extent determines the quality of our private lives, it also affects the sphere of the family, which was clearly shown by Dirk van de Kaa's Second Demographic Transition theory, created by him with Ron Lesthaeghe, it describes the decline in fertility rates below the level of volatility guaranteeing generations in European countries since the early sixties. This decrease is related to the overvaluation of the family, returning to the values of individualistic, self-fulfillment, professional work (http://www.mojasocjologia. pl/ articles.php?article_id=147). D. van de Kaa describes these changes as "a 
transition from traditional marriage to cohabitation, the shift of focus from children to adults, replacement of the preventive contraception with conscious procreation, the shift from a homogeneous type of family and household for a variety of forms" (Kurkiewicz 2011; van de Kaa 2002). This theory is confirmed by the Central Statistical Office, according to which "the results of the latest long-term forecasts of the Polish population for the years 2008-2035 shows that in the next 28 years, (...) the numbers of Polish population will steadily decrease, the rate of decline will become higher with the passage of time" (Waligórska, Nowak 2008, p. 1). Ulrich Beck also writes about the impact of postmodernity on the shape of the modern family, liberating women from their traditional roles, which is considered an irreversible process (Beck 2002, p. 170-172).

In Poland, we can observe significant changes in attitudes towards the family, alternative forms of marital life and sexuality, although the picture that emerges from the research is highly ambiguous. Poles are marrying later, divorcing more often, live in cohabitation relationships or alone; they also declare their increasingly liberal views associated with these spheres of life (Boguszewski 2008, p. 2). Even though most respondents expressed a desire to be a parent, it cannot be ignored that an increasing number of people are undecided on this issue, reflecting the weakening of the family with child model (Kowalczuk 2010b, p. 3). It is interesting that women who already have children "are far more reluctant to enlarge the family, than men with children. Women's attitude towards planning another child probably results from the fact that household responsibilities fall predominantly on them, and having a baby affects their careers to a greater extent than on the careers of their husbands (partners)" (Kowalczuk 2010b, p. 16). Still the traditionalism of Polish society is vivid and can be characterized by the fact that "family values in the declarations of Poles are still most important, and family bonds in their lives are not significantly reduced despite the time flow" (Boguszewski 2008, p. 20); 4/5 persons still childless, under 30 years of age want to have children (Kowalczuk 2010b, p. 3), but "the stronger relationship with the church by people without children, the more frequent declarations about planning offspring in the future" (Kowalczuk 2010b, p. 9-10). As for life goals, more or less the same people declare that work is most important for them, than those who point to the family (40\% and $41 \%$ ), while men more often choose work, and women choose family (Kowalczuk 2010a, p. 2). The Public Opinion Research Center study from 1998 shows that only one in seven respondents said that "parents have their own lives and do not have to sacrifice their own good for the good of children" (Falkowska 1998, p. 3), while 76\% said that "parents should do in their lives everything which is possible for their children, even at the expense of their own good" (Falkowska 1998, p. 3). According to Krystyna Slany, "Polish family cherishes a strong model »child with their parents « (the king-child with parents), not a model of »parents with a child « (the king-pair with a child)" (Slany 2008, p. 247-248).

However, in spite of all these results, which show that the sphere of higher values has not transformed and "in axiological-normative level, there are no radical changes that would make a revolution in the sphere of marriage and family" (Slany 2008, p. 247-248), and young people are mostly traditionalists - in spite of 
that there are visible some changes in attitudes and behaviors. They can be described as "in many aspects similar (...) to those manifested and performed by their peers in Western countries" (Slany 2008, p. 247-248). Perhaps they are a manifestation of the increasing individualization and liberalization. A significant force supporting these two phenomena, is mass culture, which "because of its, dictated by commercial considerations, hedonistic image (...) is often depicted as a force of anarchic and subversive nature: stopping the old taboos in the name of pleasure, and impelling to abandon the established social roles and ways of life" (Rymarczyk 2006, p. 158).

It should be remembered that examining values which are adhered to by respondents is always exposed to mistakes and inaccuracies because of its complicated nature. We can distinguish values felt and recognized (Ossowski 2000, p. 73), while the latter means that although they are not directly emotionally attractive for us, we consider them as objectively important. Therefore, they often direct our behavior, especially when we are afraid of the possible social consequences of behavior contrary to them (Ossowski 2000, p. 75).

All this makes that examination of problems related to motherhood become very difficult. Is it possible to investigate the constancy of The Polish Mother's pattern today? Perhaps a good idea would be to apply the scale proposed by Jacek Santorski, according to which "we can say that there is a factor of The Polish Mother, for example, a 10- point scale, which women have in them. Its male equivalent would be a complex of The Polish Mother, who through her dedication makes them feel guilty. Her role is dangerous for the partnership, based on responsibility, respect. Nevertheless, neurotic attractiveness of this pattern is very large in Poland. Women, in exchange for sacrifice are taking the power at home, and for men it is simply convenient" (Podgórska, Kapecka 2003, p. 92-95). But this attitude is changing and it's perfectly visible when we compare responses, about the roles in which young women saw themselves while entering adulthood. In 1979, most of them (53.3\%) perceived themselves as "a woman caring for a house, wife and mother" (Titkow, Duch-Krzystoszek, Budrowska 2004, p. 160), while in 2002 as "a woman equally reconciling home and work" (62.3\%). The desire to carry themselves mainly in the family circle decreased by $17.5 \%$. Besides, those women who saw themselves primarily in the roles of wife and mother, "are more controlled by the outer world and have a more negative self-image" (Titkow, Duch-Krzystoszek, Budrowska 2004, p. 165). So maybe it's time to overthrow the myth of the ideal mother, a mother who always commits herself to others, a mother who always chooses her child's welfare and not her own plans and desires? Is it really true that "Poles are satisfied with the role that was designated for them by society" (Ksieniewicz 2004), are they "contented slaves" (Ksieniewicz 2004) as Henryk Domański calls them? This is a very important question, because "the belief that "man is the head and woman is the neck, which turns it « reflects the nature of the apparent power enjoyed by Polish women (...) and increases (...) a compensation myth of The Polish Mother" (Ksieniewicz 2004), often harmful to the psychological well-being of many women who felt social pressure, unable to even admit that 
motherhood is not just a simple sum of the joy that they sometimes cannot cope, that they have had enough (Sokolińska 2011).

Maybe it's time to start to follow slogans which the portal nowamatkapolka.pl announces: "The New Polish Mother especially appreciates and loves herself", "We dissociate ourselves from the stereotype of the tortured Polish Mother" and "Motherhood is not a treadmill and chains, but a creative challenge" (http:/ / www.nowamatkapolka.pl/). The founder of this site speaks directly: "I I am the voice of the generation" (http:/ / www.nowamatkapolka.pl/). At the same time, the question arises as to whether it is possible to escape from this myth, without constructing another, which would take its place. Izabela Kowalczyk (Kowalczyk 2011) wonders by what model The Polish Mother would be replaced - businesswoman taking care of her appearance, but also self-realization, conscious of her needs, liberated, modern, or the "hyper-resourceful" mother from the advertisements, which ideally takes care of the house and family? The author emphasizes the role of popular culture, which produces pressure against women, often internally contradictory, that they should simultaneously be good-looking, achieve success in the workplace, but also dedicate themselves entirely for the benefit of children and husband, perform all household duties and have more time for themselves. It is worth noting that popular culture along with the ideology of consumerism may be a strategy to tackle the myth of The Polish Mother, but at the same time they can create a danger of falling into another myth-modern, eternally young and beautiful, successful women, or "super-mother". The fact that modern woman realizes herself also at work, "does not mean (...) at all, that she allows herself a more concessionary approach to the role of mother, Sharon Hays wrote. She described a pattern of views on the proper way of parenting as »the ideology of intensive motherhood «. According to it, appropriate child-raising requires a huge amount of effort, time, energy and money" (Hays 1996 in Titkow, Duch-Krzystoszek, Budrowska 2004, p. 206). The role of the mother is probably the most responsible in society. On the one hand, we can speak of a "mother-ideal", on the other a "mother-everything guilty" because she bears full responsibility for the child's life, his development, health, intelligence, behavior, etc. (Hays 1996 in Titkow, Duch- Krzystoszek, Budrowska 2004, p. 206). Unfortunately, it is often forgotten that "motherhood is work that must be learned" (Hays 1996 in Titkow, Duch- Krzystoszek, Budrowska 2004, p. 207).

It can be said that the question of The Polish Mother myth validity is in part a question of whether, in today's Poland the individual or society as a whole is more important, whether the culture of individualism, or collectivist, freedom of the individual citizen or community pressurewins. Finally it is the question of whether a woman can live for herself, or just for others. A mother does not need to be someone who is completely selfless and dedicated to the family, at every step heroically demonstrating her love. A mother can have many different faces, can explore motherhood in her own way and not try to implement standards-ideals by force. She has the right to be herself and be for herself. 


\section{BIBLIOGRAPHY}

Bauman Z. (2004), Ponowoczesność jako źródło cierpień, Sic!, Warszawa.

Beck U. (2002), Społeczeństwo ryzyka. W drodze do innej nowoczesności, Wydawnictwo Naukowe Scholar, Warszawa.

Boguszewski R. (2008), Kontrowersje wokół różnych zjawisk dotyczacych życia małżeńskiego i rodzinnego, Raport z badań CBOS, BS/54/2008, Warszawa.

Brach-Czaina J. (ed.) (1997), Od kobiety do mężczyzny i z powrotem. Rozważania o płci w kulturze, Trans Humana, Białystok.

Budrowska B. (2000), Macierzyństwo jako punkt zwrotny w życiu kobiety, Funna, Wrocław.

Budrowska B. (1997), Macierzyństwo: instytucja totalna?, [in:] Brach-Czaina J. (ed.), Od kobiety do mężczyzny i z powrotem. Rozważania o ptci w kulturze, Trans Humana, Białystok.

Davies K. (1994), The Tensions between Process Time and Clock Time in Care Work, "Time and Society", vol. 3 (3).

Dmochowska H. (2007), Kobiety w Polsce, Główny Urząd Statystyczny, Warszawa.

Falkowska M. (1998), Wychowanie dzieci w rodzinie i opieka nad nimi, Raport z badań CBOS, BS/168/168/9, Warszawa.

Graff A. (2008), Rykoszetem. Rzecz o ptci, seksualności i narodzie, W.A.B., Warszawa.

Kobiety przeciw feministkom (2003), "Polityka" 27.09.2003.

Kowalczuk K. (2010a), Cele i dążenia życiowe Polaków, Raport z badań CBOS, BS/161/2010, Warszawa.

Kowalczuk K. (2010b), Postawy prokreacyjne Polaków, Raport z badań CBOS, BS/4/2010, Warszawa.

Monczka-Ciechomska M. (1992), Mit kobiety w polskiej kulturze, [in:] Walczewska S. (ed.), Głos maja kobiety. Teksty feministyczne, Convivium, Kraków.

Ossowski S. (2000), Z zagadnień psychologii społecznej, PWN, Warszawa.

Ost D. (2007), Klęska "Solidarności". Gniew i polityka w postkomunistycznej Europie, Warszawskie Wydawnictwo Literackie Muza, Warszawa.

Płeć a możliwości ekonomiczne w Polsce: czy kobiety stracity na transformacji? (2004), Report of the World Bank under the supervision of P. Paci, Poverty Reduction and Economic Management Unit of the Europe and Central Asia, Washington DC.

Podgórska J., Kapecka J., Cień Matki Polki, “Polityka”, 24.05.2003.

Rymarczyk P. (2006), Hedonizm a konserwatyzm: rozważania nad ideologią w kulturze masowej, [in:] Żuk P. (ed.), Media i władza. Demokracja, wolność przekazu i publiczna debata w warunkach globalizacji mediów, Wydawnictwo Naukowe Scholar, Warszawa.

Slany K. (2008), Alternatywne formy życia matżeńsko- rodzinnego w ponowoczesnym świecie, Nomos, Kraków.

Sulik M. (2010), Kobiety w nauce. Podmiotowe i społeczno-kulturowe uwarunkowania, Wydawnictwo Uniwersytetu Śląskiego, Katowice.

Środa M. (1992), Kobiety: wychowanie, role, tożsamość, [in:] Walczewska S. (ed.), Głos maja kobiety. Teksty feministyczne, Convivium, Kraków.

Titkow A. (ed.) (2003), Szklany sufit. Bariery i ograniczenia karier kobiet. Monografia zjawiska, Fundacja Instytut Spraw Publicznych, Warszawa.

Titkow A., Duch-Krzystoszek D., Budrowska B. (2004), Nieodptatna praca kobiet. Mity, realia, perspektywy, Wydawnictwo Instytutu Filozofii i Socjologii PAN, Warszawa.

Walczewska S. (1999), Damy, rycerze i feministki. Kobiecy dyskurs emancypacyjny w Polsce, "eFKa”, Kraków.

Walczewska S. (ed.) (1992), Głos mają kobiety. Teksty feministyczne, Convivium, Kraków.

Waligórska M., Nowak L. (2008), Prognoza ludności Polski na lata 2008-2035,Główny Urząd Statystyczny, Warszawa.

Żuk P. (ed.) (2006), Media i władza. Demokracja, wolność przekazu i publiczna debata w warunkach globalizacji mediów, Wydawnictwo Naukowe Scholar, Warszawa.

\section{NETOGRAPHY}

Brzezińska M. (2011), Feminizmem w kobietę, http://www.fronda.pl/news/czytaj/tytul/feminizmem_w_kobiete, retrieved: 28.10.2011.

http://mlot.blogspot.com/search/label/Feminizm, retrieved: 28.10.2011.

http://www.nowamatkapolka.pl/, retrieved: 21.11.2011. 
http:/ / www.mojasocjologia.pl/articles.php?article_id=147, retrieved: 21.11.2011.

Kowalczyk I. (2011), Matka-Polka kontra supermatka?, http:/ / free.art.pl/artmix/archiw_7/matkapolka. html, retrieved: 28.10.2011.

Ksieniewicz M. (2011), Specyfika polskiego feminizmu, “Kultura i Historia” 2004, 6, http:/ / www.kulturaihistoria.umcs.lublin.pl/archives/169, retrieved: 21.11.2011.

Kurkiewicz J. (2011), Zasoby pracy krakowskiego obszaru metropolitalnego na tle demograficznych przemian w środowisku wielkomiejskim, http://www.stat.gov.pl/cps/rde/xbcr/gus/POZ_Zasoby_pracy_krakowskiego_obszaru_metropolitalnego.pdf, retrieved: 21.11.2011.

Lisowska E. (2011), Przyszłość pracy a kobiety, http://www.pracujacyrodzice.pl/dokumenty/Przyszlosc_pracy_a_kobiety.pdf, retrieved: 28.10.2011.

Łazar-Massier M. (2011), Maryja cielesna, http://free.art.pl/artmix/archiw_3/0102mlm.html, retrieved: 8.11.2011.

Marciszewski W. (2011), Zanikanie mitu społecznego, http://www.calculemus.org/lect/10metod/02-mit.pdf, retrieved: 20.11.2011.

Puigarnau J. A. (2009), Equality between women and men - 2010, http:/ / eur-lex.europa.eu/LexUriServ/ LexUriServ.do?uri=SEC:2009:1706:FIN:EN:PDF, retrieved: 28.10.2011.

Punpur M. (2011), Logika mitu, http:// www.racjonalista.pl/kk.php/s,5337/q,Logika.mitu, retrieved: 20.11.2011.

Rutkowska Z. (2011), Kobiety Solidarności, http://obywatelki.pl/Community/Blog.aspx?BlogEntryId=58914, retrieved: 28.10 .2011 .

Sokolińska J. (2011), Matki Polki poświęcające się, “Wysokie Obcasy”, http://www.wysokieobcasy.pl/ wysokieobcasy/1,53664,6973090,Matki_Polki_poswiecajace_sie.html, retrieved: 21.11.2011.

van de Kaa D. J. (2002), The Idea of a Second Demographic Transition in Industrialized Countries, http:// www.ipss.go.jp/webj-ad/WebJournal.files/population/2003_4/Kaa.pdf, retrieved: 21.11.2011.

Ziemkiewicz R. (2011), Męskie, żeńskie, polskie, http:// www.rp.pl/artykul/61991,729438.html, retrieved: 28.10.2011. 